University of Michigan Law School

University of Michigan Law School Scholarship Repository

\title{
The Domicil of Persons Residing Abroad under Consular Jurisdiction
}

\author{
Edwin D. Dickinson \\ University of Michigan Law School
}

Available at: https://repository.law.umich.edu/articles/959

Follow this and additional works at: https://repository.law.umich.edu/articles

Part of the Comparative and Foreign Law Commons, and the Jurisdiction Commons

\section{Recommended Citation}

Dickinson, Edwin D. (1919-1933). "The Domicil of Persons Residing Abroad under Consular Jurisdiction." Mich. L. Rev. 17, no. 6 (1919): 437-55.

This Article is brought to you for free and open access by the Faculty Scholarship at University of Michigan Law School Scholarship Repository. It has been accepted for inclusion in Articles by an authorized administrator of University of Michigan Law School Scholarship Repository. For more information, please contact mlaw.repository@umich.edu. 


\section{MICHIGAN \\ LAW REVIEW}

\begin{tabular}{lll}
\hline Vor. XVII. & APRIL, I919 & No.6 \\
\hline
\end{tabular}

\section{THE DOMICIL OF PERSONS RESIDING ABROAD UNDER CONSULAR JURISDICTION}

\footnotetext{
$\mathbf{T}$
}

$\mathrm{HE}$ domicil of persons living under consular jurisdiction in foreign countries presents a problem of unique importance, not only because of the concern which a large number of people have in its proper solution, but also because of its relation to the conception of domicil and to the requisites by which the existence of demicil is to be determined. This problem may be concisely. stated in the form of a question as follows: Is it possible for a person residing abroad under consular protection to acquire a domicil of choice in the country of residence? There are no apparent obstacles to the acquisition of such a domicil, and on superficial consideration it would seem that the question might be readily answered in the affirmative. The question has been answered in the affirmative after careful consideration, in the only American cases in which the precise point has been raised. ${ }^{1}$ The English courts, on the other hand, seem to be fully committed to the contrary view. The Court of Appeal has decided, in the recent case of Casdagli v. Casdagli, ${ }^{2}$ that a British subject cannot acquire a domicil of choice under such circumstances. The conflict of judicial opinion thus presented may be approached most advantageously through a preliminary consideration of the antecedents of the English rule.

There are several factors of which account must be taken if one is to understand the difficulty which the English courts have experienced in arriving at a solution of the problem. In the first place, there has always been a rather deeply rooted judicial prejudice against the notion of Christian domicil in heathen. lands.

In re Allen's Will, United States Court for China, Term at Shanghai, August, 1907, in I American Journal of International Law 1029; Mather v. Cuntringham, ros Me. 326 (I909).

287 L. J. P. 73 (1917). 
Lord Stowell's famous dictum in The Indian Chief with regard to the immiscible character of European settlements in the Orien ${ }^{3}$ has been quoted many times. Dr. Lushington declared in Maltass v. Maltass that "every presumption is against the intention of British Christian subjects voluntarily becoming domiciled in the dominions of the Porte." More recently, in the case of The Derffinger (No. I), it has been asserted that "the waters of Alpheus still flow undefiled, and where European Powers enjoy the privilege of ex-territorial jurisdiction their subjects never lose their native character." The importance of this factor cannot be measured with exactness, but it is quite clear that it has had an appreciable influence upon the course of judicial decisions.

Another source of difficulty has been the disposition to seek an analogy in the rule of the prize courts as to commercial domicil under exterritorial jurisdiction. The British prize courts have held consistently that the neutral or enemy character of persons engaged in trade in foreign countries under exterritorial protection is to be determined by the character of the state which exercises such protection. The leading authority on the point is Lord Stowrell's famous judgment in The Indian Chief, ${ }^{\text {, }}$ where it was held that the neutral or enemy character of a person engaged in trade in the Orient under the protection of a European association or factory is to be determined by the character of the association or factory. Lord Stowell remarked that .

"in- the East, from the oldest time, an immiscible character has been kept up; foreigners are not admitted into the general body and mass of the society of the nation; they continue strangers and sojourners as all their fathers were-Doris amara suam non intermiscuit undam; not acquiring any national character under the general sovereignty of the country, and not trading under any recognized authority of their own original country, they have been held to derive their present character from that of the association or factory, under whose protection they live and carry on their trade."

The modern application of Lord Stowell's principle has been made during the recent war by the British prize courts for Egypt. In the

\footnotetext{
${ }_{3}$ C. Rob. 12, 29.

I Rob. Eccl. 67,80 .

s I Br. \& Col. P. C. $386,388$.

- 3 C. Rob. 12, 22 (1800).

${ }^{2} 3$ C. Rob. I2, 22, 29. See Piggott, Exterritoriality (new ed.), 222. Compare The Eumaeus, I Br. \& Col. P. C. 605, 613 (Igr5).
} 
case of The Derffinger (No. I), ${ }^{8}$ a neutral commercial domicil was claimed for a German subject residing in China under German consular jurisdiction; but it was held that an eneny subject cannot acquire a commercial domicil outside the country of his allegiance by residing abroad under the jurisdiction of his country's consular courts. President Cator quoted the language of Lord Stowell with approval, and continued:

"In those,days factories, as they were called, still flourished in the Orient $* * *$ Since that time the grouping has undergone a change. Communities which in those days were not. trading under any recognized authority of their own original country have now sorted themselves out into communities of different nations, definitely controlled by their home Governments, which legislate for them in virtue of rights acquired by custom or definitely conceded by native potentates. The trading bond has given way to one of nationality. But allowing for this difference, the words of Lord Stowell are just as applicable in these days as they were more than a hundred years ago. The waters of Alpheus still flow undefiled, and where European Powers enjoy the privilege of ex-territorial jurisdiction their subjects never lose their native character. Each community continues its distinctive existence, governed by its own consuls and subject to the laws of its mother country."

President Cator was not inclined to assimilate commercial domicil as a test of neutral or enemy character to civil domicil gènerally. ${ }^{10}$ A somewhat different attitude was taken in the later case of The Ifitzow and The Koerber.11 It was claimed that goods shipped

I Br. \& Col. P. C. 386 (1915).

I Br. \& Col. P. C. $3^{86,} 3^{88 .}$

10 That he regarded the question of commercial domicil as essentially different from that of civil domicil is shown by the following passage from his opinion: "From time to time questions as to the status of British subjects in China and the Ottoman Dominions have come before our Courts, and it has been settled that no British subject can change his legal domicile, by residence in any place where the Crown has ex-territorial authority. That, as we know to our cost, owing to the great inconvenience which it has entailed upon the British community, is, I think, the effect of In re Tootal's Trusts * "approved of by the Privy Council in Abd-ul-Messih $\nabla$. Farro * * These decisions, it is true, relate only to the subtle and artificial doctrine of personal domicile which has been evolved by our civil Courts for the purpose of determining questions relating principally. to probate and. administration; and a legal domicile for the purpose of a Court of Probate is, I' need hardly say, a very different thing from a commercial domicile for the purpose of a Prize Court." I Br. \& Col. P. C. 386, 389. The two cases cited by President Cator are dis. . cussed irfra.

II I Br. \& Col. P. C. 528 (1915). 
by German merchants in China should be regarded as neutral property because the owners had acquired a neutral commercial domicil. Counsel conceded that it might be impossible to acquire a civil domicil under similar circumstances, but contended that the arguments against civil domicil were not applicable because civil and commercial domicil are fundamentally different. The Court held that commercial domicil cannot be established under consular jurisdiction, and expressed the opinion that to a considerable extent at least the arguments against civil domicil may be applied to defeat a claim of commercial domicil. Judge Grain concluded,

"Although I have been much impressed by the judgment in Mather v. Cunningham ${ }^{12 * * *}$ and the review of the British cases in that judgment, nevertheless I am of opinion that at the present time the British law is that neither a civil nor a commercial domicil can be established by an individual who is resident or carrying on business in a foreign land when his country has been granted the privileges of extra-territoriality."18

It is not necessary to consider here the usefulness in prize cases of an analogy between civil and commercial domicil under exterritorial jurisdiction. On the other hand it seems clear enough that the rules of commercial domicil by which prize courts determine neutral or enemy character do not furnish a helpful analogy in solving the more difficult problem of civil domicil. Commercial and civil domicil are fundamentally different. ${ }^{14}$ Indeed, the point would be almost too obvious for comment if the prize cases had not been invoked so persistently in arguing the question of civil domicil.

The anomalou's notion of Anglo-Indian domicil has been the source of much more serious confusion. This notion grew up during the rule of the East India Company in India. British subjects in the service of the Company in India were held to acquire

12 Discussed infro.

Is I Br. \& Col. P. C. 528, 532. "It is clear from the cases Maltass v. Moltass" * Tootal's Trusts, In re** and Abd-ul-Messih v. Farra** that in British law a civil domicile cannot be established in countries where extra-territoriality runs." Ibid., 530.

14 See Dicey, Conflict of Laws, app., notes 3 and 4 . "But such factories are not regarded as colonies or foreign countries for the purpose of domicil. There may be commercial domicil there in times of war with reference to the law of capture, but that is altogether a different matter." Per Justice Chitty, in In re Tootal's Trusts, $23 \mathrm{Ch} . \mathrm{D}$. 532, 540. "Commercial domicil' differs in so many respects from 'civil domicil' that I do not think these cases useful in dealing with the present question." Per Lord Justice Scrutton, in Casdagli v. Casdagli, 87 L. J. P. 79, 89. 
what was called an Anglo-Indian domicil. ${ }^{15}$ The doctrine is summarized in The Laivs of England as follows :

"An exception to the ordinary rules governing the acquisition of a domicil of choice formerly existed in the case of British subjects in the service of the East India Company residing in India for a period of service that was not fixed. The government of the Company was regarded as a foreign government, and entry into its service as imposing a duty which was incompatible with the retention of an existing domicil; and a presumption, which was not allowed to be rebutted, was raised in favour of an intention consistent with this duty. An Indian domicil was therefore acquired by mere residence in India under these conditions, without regard to the actual state of mind accompanying it, and in spite of the fact that the majority of the Company's servants definitely looked forward to their return. This anomalous domicil has never been acquired by the servants of the Crown in India. and since 1858 the mode in which an Indian domicil is acquired has ceased to be exceptional."16

The domicil of British subjects not in the service of the East India Company, who settled in India for the purpose of trade, was not.infrequently referred to as Anglo-Indian, ${ }^{17}$ and the distinction between the two kinds of cases was not always carefully observed. The doctrine of Anglo-Indian domicil was admittedly anomalous. It lost its practical importance after the establishment of direct British rule in India. Curiously enough, it has been invoked as a precedent in every case involving the question of domicil under consular jurisdiction.

Antipathy to the idea of Christian domicil in heathen countries and appeals to false analogies, particularly to analogies with the rule as to commercial domicil and with the doctrine of Anglo-Indian domicil, contributed to produce a somewhat unusual confusion. The conception of domicil was distorted, and the accumulated dicta of distinguished judges became the foundation for the anomalous rule laid down by the Court of Appeal in the Casdagli case. The

23 See Bruce v. Bruce, 2 B. \& P. 229 (1790); Craigie v. Lewin, 3 Curt. 435 (1843); Forbes v. Forbes, 23 L. J. Ch. 724 (1854); Hepburn v. Skirving, 9 W. R. 764 (1861); Jopp v. Wood, 34 L. J. Ch. 212 (1865); Ex parte Cunningham, 13 Q. B. D. 418 (1884). 10 VI, p. 190 .

${ }^{17}$ See Cockrell v. Cockrell, 25 L. J. Ch. 730 (1856); The Attorney General v. Fitzgerald, ibid.. 743 (1856); Lyall v. Paton, ibid., 746 (1856); Allardice v. Onslow, 33 L. J. Ch. 434 (1864). 
first case in which the acquisition of a domicil of choice under consular jurisdiction was considered was Maltass. v. Maltass. ${ }^{18}$ The testator was born and settled all his life at Smyrna. His father had been domiciled at a remote period in England. 'The will was valid under English law, but it was contended that the testator had been domiciled in Turkey and that by Turkish law he could not dispose of his property by will. Dr. Lushington remarked at the outset that an inquiry as to domicil would be unnecessary if it should appear that, with respect to this particular succession, the law of England and the law of Turkey were the same; and in concluding his opinion he said:

"I wish to observe that I am desirous not ta be supposed to have given an opinion upon any question not necessary to be decided in this case. My judgment therefore does not affect the question of domicil. - If the deceased was in the legal sense domiciled in Turkey, and if the law of domicil does prevail, the law of Turkey in conformity with the treaty says that in such case the succession to personal estate shall be governed by the British law; if he was not dorniciled in Tur. key but in England, then the law of England prevails proprio vigore. ${ }^{19}$

I give no opinion, therefore, whether a British subject can or cannot acquire a Turkish domicil; but this I must say,I think every presumption is against the intention of British

- Christian subjects voluntarily becoming domiciled in the dominions of the Porte. As to British subjects, originally Mus'sulmen, as' in the East Indies, or becoming Mussulmen, the same reasoning does not apply to them as Lord Stowell has said does apply in cases of a total and entire difference of religion, customs, and habits."20

\footnotetext{
18 I Rob. Eecl. 67 (I844).

10 Westlake's punctuation of this paragraph has been followed in preference to the obviously defective punctuation of the report. Westlake, Private International Law (4 ed.), 338.

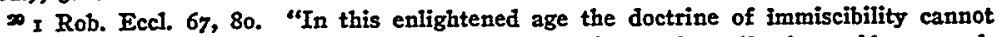
be accorded such weight as to establish a legal presumption against all other evidence tending to prove animus. In American-jurisprudence, at least, it should be allowed to slumbar with Quaker persecution, Salem witcheraft and other kindred dogmas. Since the dictum of immiscibility was first declared, the world has experienced a revolution touching the national, commercial and trade relations between the nations of the East and those of the West. Our conciusion, therefore, upon the first proposition is that no sound reason can be adduced against the practical application of the American law of domicil to Americans residing in China, when the animus et factum are found to concur." Per Justice Spear, in Mather v. Currtingham, $105 \mathrm{Me}$. 326, 34r.
} 
It is evident that Dr. Lushington's remark on the subject of domicil was dictum. The question of domicil under consular jurisdiction was expressly left undecided.

The question might have been decided, had it been properly submitted, in the famous case of In re Tootal's T-rusts. ${ }^{21}$ The testator was a British subject who had resided for a long period at Shanghai and hàd manifested an undisputed animus manendi. The liability of his personal estate to the English legacy duty depended upon his domicil at death. On the one hand, an argument that the testator had acquired a Chinese domicil would encounter Dr. Lushington's dictum as to the presumption against an intention to acquire such a domicil..2 On the other hand, an argument that the testator had acquired an Anglo-Chinese domicil could be supported by an analogy with the doctrine of Anglo-Indian domicil. It is perhaps not surprising, although none the less unfortunate, that counsel elected the latter alternative. Counsel admitted that the testator's domicil was not Chinese, apparently meaning that he had not intended to subject himself to the law applicable to Chinamen, and contended that his domicil was Anglo-Chinese, apparently meaning that he was subject to the law which applied to Englishmen in China. ${ }^{25}$ With regard to the admission of counsel, Mr. Justice Chitty said:

"This admission was rightly made. The difference between the religion, laws, manners, and customs of the Chinese and of Englishmen is so great as to raise every presumption against such a domicil, and brings the case within the principles laid down by Lord Stowell in his celebrated judgment in The Indian Chief, and by Dr. Lushington in Maltasis v. Maltas̄s."2t

It was held that the doctrine of Anglo-Indian domicil was inapplicable, ${ }^{2 \pi}$ that there was no such thing known to the law as Anglo-Chi-

23 Ch. D. 532 (1883). See Westlake, "Domicile at a Chinese Treaty Port," in 9 Law Magazine and Review (4th series) 363-382.

2 It would seem that the existence of exterritorial jurisdiction ought to make it easier to find the necessary animus, for in selecting a new domicil of choice the fact that his affairs would be governed by the law of his own country would tend naturally to infiuence a person in favor of the new domicil. See 58 Univ. of Penn. Law Review 543, 548.

2 The argument was summarized by Justice Chitty in the opinion as follows: "Upon these facts it is contended for the Petitioners that there exists at the foreign port of Shanghai an organised community of British subjects independent of-Chinese law and exempt from Chinese jurisdiction, and not amenable to the ordinary tribunals of this country, but bound together by law which is English law, no doubt, but English law with this difference, that the English revenue Iaws, do not form part of it, and that by residence and choice the testator became a member of this community, and as such acquired an Anglo-Chinese domicil." $23 \mathrm{Ch}$. D. 532, 536.

${ }^{24} \mathrm{Ch}_{2} \mathrm{D} .532,534$.

23 "At Sharghai there is a British consul, residing there by virtue of the treaties, but 
nese domicil, and that the testator must have retained his Finglish domicil of origin. In the course of his opinion Mr. Justice Chitty said:

"There is no authority that I am aware of in English law that an individual can become domiciled as a member of a community which is not the community possessing the supreme or sovereign territorial power." 26

When taken out of its context, this remark has been the source of considerable embarrassment; but, considered in relation to the precise point which Mr. Justice Cristixy had to decide, it seems to be free from difficulty. In any event, the question of the acquisition of domicil in China by a person enjoying consular protection was not squarely submitted to the court. The most important question was eliminated by the admission of counsel, and the court was asked and refused to find not a Chinese but an anomaloús Anglo-Chinese domicil analogous to Anglo-Indian domicil. Tootal's Trusts is at best a frail support for-the decision of the Court of Appeal in Casdugli v. Casdagli.

. The authority of $A b d-u l-M e s s i h$ v. Clutkri Farra, ${ }^{2 \pi}$ in which Mr. -Justice Chitty's dictum was approved by the Judicial Committee of the Privy Council, is still more dubious. The testator in this case was born at Bagdad an Ottoman subject. In early life he went to India, where he remained for a considerable period. Later he went to Jeddah, and afterwards to Cairo, where he lived for twenty-seven years under the protection of the British Government. On his death the question arose as to the law which should determine his power of testacy and the distribution of his effects. It was argued that by making his permanent home in Cairo under British protection the testator had acquired an Anglo-Egyptian domicil, or at least an Egyptian as distinguished from a Turkish domicil. The latter point was not atgued in the consular court, however, and was dismissed very briefly by the Judicial Committee on appeal. The Judicial Committee found Tootal's Trusts "an authority directly in point," and held that an Ottoman subject could not acquire an AngloEgyptian domicil of choice by residing in Egypt, then Ottoman territory, under British protection, because domicil depends on locality and not on membership in a protected community. Lord Watson

there is no government by British authority existing there, and there is nothing which can be regarded as a separate or independent Government, and the analogy which the Pctitioners seek to establish with an Anglo-Indian domicil is not made out." $23 \mathrm{Ch}$. D. 532, 538.

${ }_{23}$ Ch. D. 532, 538. See Westlake, Private International Law (4 ed.), 318-319.

Ir 13 App. Cas. 43I (1888). 
remarked that "residence in a foreign country, without subjection to its municipal laws and customs, is therefore ineffectual to create a new domicil," and also that

"residence in a foreign State, as a privileged member of an exterritorial community, although it may be effectual to destroy a residential domicil acquired elsewhere, is ineffectual to create a new domicil or choice." 28

The authority of Tootal's Trusts on the point at issue in $A b d-u l$ Messilz v. Ckskki Farra has never been satisfactorily explained. The two cases apparently had little in common. The passages quoted from Lord Watson's opinion seem to have gone somewhat beyond the point to be decided.

- The suggestion that residence under consular jurisdiction should be ineffectual to create a new domicil of choice was not favorably received among the jurists. William Edward Hall regarded the law as settled by Tootal's Trusts and $A b d-u l-M e s s i h$ v. Chiukri Far$r a$, but regretted that a change in the law had not been made by Order in Council.

"It is perhaps to be regretted that a change in the law is not made which a short Order in Council could easily effect. Anglo-Oriental domicil has its reasonable, it may almost be said, its natural place. Conflicts between the differing laws of England, of Scotland, of the various self-governing colonies, are inevitable within British jurisdiction in the East; but it is unnecessary to multiply the points of collision. So long as persons have not identified themselves with the life of a new community, they must each keep his own law; but as soon as they have shown their wish and intention to cut themselves adrift from the association of birth, they prove their indifference to the personal law attendant.on their domicil of origin; there is, therefore, no reason why simplicity and unity of law should not be gained for British subjects by attributing community in the laws of England to all of European blood." 20

The late Professor Westlake regarded the whole question as unsettled, and thought that it called for further examination by the House of Lords or the Privy Council. ${ }^{30}$ Sir Francis Piggott, -whose

\footnotetext{
2013 App. Cas. 43x, 439, 445. The case was cited with approval, although the point under consideration was not involved, in Abdallah v. Rickards, 4 T. L. R. 622 (1888).

2 Foreign Jurisdiction of the British Crown, 180-186," 184 .

" Private International Law (4 ed.), 311-322,- 32r. See also 9 Law Magazine and Review (4th series) $363-382$.
} 
opinion is especially valuable because of his experience as Chief Justice of Hong Kong, did not think that Tootal's Trusts had promoted a final solution of the problem and he expressed the opinion that when the question was again raised it would be found that "the principles established by the most recent cases necessitate a re-consideration of the law laid down on this subject by Mr. Tustice Chitty."31 A more recent study of the subject by Mr. Charles $H$. Huberich leads its author to the following conclusion:

"The acquisition of a domicile in a country granting exterritorial privileges is governed by the same principles of law as the acquistion of a domicile in other countries. Where 'the requisite factum and animus are shown to exist there is no valid reason why an Englishman or an American should not be held to acquire a domicile in China. In respect of all matters which private international law refers to the law of the domicile he would be governed by the Chinese law, the law af the territorial sovereign. The law to which he would be subject would be none the less the law of China because it provides that persons of British and American nationality shall be governed by such laws as their respective countries may enact to goven their nationals in China."32

The suggestion that a domicil of choice cannot be acquired under consular jurisdiction has been repudiated in the only American jurisdictions where the question has been raised. In the case of In re Allen's Will, ${ }^{33}$ before the United States Court for China, the testator was born in Georgia, moved to China when twenty-four years of age, and lived there for twenty-seven years, until his death, engaged in his labors as a missionary. His family was reared in China and his estate, consisting solely of personal property, was accumulated there. He expressed an intention on several occasions to makeChina his permanent home, but never abandoned his American citizenship. It was held that the testator had acquired an "extraterritorial domicil"34 in China, and that the administration of his es-

81 Exterritoriality (new ed.), 2r6b-235, 224, 232.

22 "Domicile in Countries Granting Exterritorial Privileges to Foreigners," 24 Law Quarterly Review 440-448, 447; also $3 \mathrm{I}$ ibid. 447-450.

Shanghai Term, August, I907, printed in I American Journal of International Law 1029.

"The term "extraterritorial domicil" was unfortunate, and has been criticized in the later American case. "We wish to say, however, that we do not agree with Judge Wilfley in employing the name "extraterritorial domicil." It appears to be inconsistent with the fundamental idea of domicil, which, as we have endeavored to show, is a relation between an individual and a particular locality or country. The fact that the law governing the 
tate should be determined by the common law which Congress had authorized the United States Court for China to apply. Judge Wilfley said,

"We can see no good reason for holding that a citizen of the United States cannot be domiciled in China. Mr. Justice Chitty's decision destroys in their application to China all the definitions of domicil contained in the books. It ignores both of the essential elements of residence and intention $* * *$ It requires a greater stretch of the imagination and the adoption of a greater fiction of law to hold that a person can be domiciled in a country where he does not reside and has no intention of residing at any future time than to hold that a citizen of a foreign State can acquire an exterritorial domicil in a community which is not the community possessing the sovereign territorial power. Every consideration of reason and convenience demands that the American law of domicil be applied by American Courts in China."35

The same question was submitted to the Maine Supreme Court in Mather v. Cunningham. ${ }^{38}$ The testator was born in Waldo County, Maine, but lived most of his life at Shanghai. His will was proved before the United States Consul at Shanghai. Two brothers filed a petition in the Probate Court of Waldo County, Maine, for administration of the estate as intestate property, contending that the decedent could not acquire a domicil at Shanghai, that he retained his domicil of origin, and that by the law of Maine the will was invalid. It was held that domicil under consular protection is to be determined by the same rules of law which control the acquisition of domicil elsewhere, that the testator had acquired a Chinese domicil, and that his will was properly sustained under the common law as administered by the American Consular Court.

In this state of the English and American authorities the precise question under consideration was squarely submitted to an English court, for the first time, it may be noted, in the case of Casdagli v. Casdagli. ${ }^{37}$ Demetrius Casdagli was born in England in 1872 of naturalized British parents. Most of his life has been spent in Egypt, where he has resided continuously since 1895 , and where he was married to a woman of Greek nationality in 1905. In his will,

particular locality is extraterritorial, does not make the domicil extraterritorial, since it is immaterial upon the question of domicil from what source the law is proclaimed, as before shown." Mather v. Cunningham, I05 Me. 326, 346.

25 I American Journal of International Law 1029, 1037.

20105 Me. 326 (1909).

9787 L. J. P. 73 (I917). 
drawn in 19I0, he described himself as "a merchant, a British-born subject having a domicil in Egypt." Throughout his residence in Egypt, Casdagli has been registered at the British consulate as a British-born subject. The British Consular Court in Egypt has no jurisdiction to dissolve marriages. In I9I6, Mrs. Casdagli petitioned the English High Court for a divorce. The Court's jurisdiction was denied on the ground that the respondent was not domiciled in Fingland and had never had a matrimonial domicil there. It was answered that the respondent had never lost his English domicil of origin. Casdagli's actual residence in Egypt and his animus manendi were established to the court's satisfaction. Justice Horridge said, "In this case $I$ think it is abundantly proved that the respondent has, apart from extra-territorial rights, voluntarily fixed his sole or chief residence in Egypt, with the intention of continuing to reside there for an unlimited time." ${ }^{\text {ss }}$ The real issue of the case, therefore, was whether the possession by Casdagli as a British subject of exterritorial rights rendered him incapable of acquiring an Egyptian domicil. Justice Horridge came somewhat reluctantly to the conclusion that he was bound by Tootal's Trusts and Abd-ul-Messih v. Chukri Farra, ${ }^{39}$ and held that Casdagli's residence and animus manenidi in Egypt as a member of the exterritorial community were ineffectual to create a new Egyptian domicil of choice. This decision was affirmed by Swinfen Eady, L. J., and Warrington, I. J., in the Court of Appeal, Scrutton, L. J., dissenting. ${ }^{40}$

The decision of the Court of Appeal in Casdagli v. Casdagli apparently rests upon the principle that domicil requires, not only the fact of residence and the animus manendi, but also what may be described as a normal relation to the laws of the country of residence. Of the case of Mather v. Cunningham, Swinfen Eady, L. J. says, "This case is not consistent with the view of domicil adopted and acted upon by English Courts. A person, settling in a country where ex-territorial

887 L.'J. P. $73,76$.

$\approx$ Justice Horridge sard: "It may be that if this case had been presented to the Court free from authority, I should have felt there was great force in the views expressed by certain jurists and in the American case on the matters dealt with in Tootal's Trusts, * * and I might have come to a conclusion which, having regard to Tootal's Trusts * * and Abd-ul-Messih, v. Chukri Farra, * * would have been a wrong decision. It may, indeed, be desirable at the present time that Britons retaining their position as British subjects should nevertheless be entitled to settle down in foreign territory and enter into the life, and take part in the institutions of other countries, and to subject themselves to the local laws of those countries, which laws include regulations for their special protection. I think, however, as the decision of Mr. Justice Chitty which affects personal status is a decision given in 1883 , and as it is supported by the great authority of the judgment of Lord Watson in the Privy Council, I am bound to follow these cases and hold that the act on petition fails upon the third objection raised by the petitioner." 87 L. J. P. 73, 78.

487 L. J. P. 79. 
privileges are granted, and who is governed by the law of his domicil of origin, cannot be said to have attracted to himself the local municipal law, when the local law is by treaty expressly excluded from applying to him." A1 And Warrington, L. J., declares that "domicil in its legal meaning is clearly something more than the mere fact of physical residence, coupled with the animus manendi. It connotes also a legal relation to the laws of the country of residence by which questions relating to the personal status of the individual are determined." $" 12$

The notion that domicil requires actual residence, the animus manendi, and a normal relation to the laws of the country of residence involves, in the opinion of the present writer, an unnecessary confusion of domicil with lex domicilii. Domicil is a legal relationship between person and place."s "Domicil of choice," said Iord Westbury, in Udny v. Udiry, "is a conclusion or inference which the law derives from the fact of a man fixing voluntarily his sole or chief residence in a particular place, with an intention of continuing to reside there for an unlimited time."44 The requisites for a domicil of choice are (I) the fact of residence, and (2) the animus manendi. "The factum required is a change of residence, voluntarily assumed, and permanent in character; the animus required is an intention to settle in a new country as a permanent residence."45 "It is plain," said Justice Spear, in Mather v. Cunningham, "that it is the place, not the local laws, that becomes of paramount importance in determining the question of domicil. Where, not under what laws, do the animus et factum concur?":46 'The lex domicilii, on the other hand, is the law which is applied in the place of domicil. Normally it is administered by the local authority, but there is no reason why it may not come from a dual source and be administered partly by local and partly by exterritorial authority.

The conception of domicil and the lex domicilii ought never to be confused. The distinction between them becomes especially important when dealing with a subject.like domicil under consular jurisdiction where the character of the lex domicilii is somewhat anomalous. The importance of the distinction is suggested in the fol-

487 L. J. P. 79, 81.

47 L. J. P. 79, 83.

a See Bell v. Kennedy, L. R. I H. L. (Sc.) 307 (1868); Udny v. Udny, I. R. I \#. L. (Sc.) 447 (1869): The Laws of England, VI, 182-196; Dicey, Law of Domicil, 33I ff.; N. W. Hoyles, "Domicile," 48 Canadian Law Journal $474 \cdot 489$.

4 L. R. I H. L. (Sc.) $44 \mathrm{I}, 458$.

4 Hoyles, in 48 Canadian Law Journal $474,47 \%$.

so5 Me. 326, 336. 
lowing passages from the dissenting opinion of Lord Scrutton in the Casdagli case.

"The first stage of the question seems to be: Is there a domicil or permanent home?-which depends on the fact of residence and the intention to continue to reside. The law of England generally determines the status of a person, who may be contended to be subject to various laws which conflict-as the lex.domicilii, the law of this national character, the lex lcci actus or solutionis-by the lex domicilii. The second stage of the enquiry is: Is there a lex domicilit which the English Courts will recognise?*** The law of the domicil would appear to be the law which the Sovereign of the domicil would administer in the case of the domiciled person. If so, can it make any difference whether the Sovereign of the domicil administers the law directly, or allows another Sovereign by grant to exercise part of his sovereignty by administering such law as he pleases in Courts which the Sovereign of the domicil allows to exist in his territory? The law appears still to be the law of the domicil, allowed to be admininistered in the country of the domicil by the sovereign power of that country, whose consent is necessary for its administration. $* * *$ As a matter of principle apart from authority, I am unable to see why the fact that the Sovereign of a country has granted to another country the privilege of exercising jurisdietion over its subjects within his dominions, according to its own law, should prevent a subject of the latter country, who resides and intends permanently to reside in the former country, from acquiring a domicil there. He will have a lex domiciliz-namely, the law which the Sovereign of the country allows to be applied to him by the Courts which that Sovereign allows to exist. $* * *$ Where the territory of residence belongs to a Sovereign, who grants or allows a certain law to exist in it for certain persons, I can see no reason in principle why there should not be a domicil and a lex domicilii."47

If the confusion of domicil and lex domicilii is objectionable, as it seems clearly enough to be, then hyphenated descriptions of domicil under consular jurisdiction, ought to be abandoned at once and for all. The terms Anglo-Chinese, Anglo-Turkish, etc. have had their distinguished proponents. "Now it would seem convenient," said

47 . L. J. P. 79, 87. It is impossible to do justice to the dissenting opinion in the Gasdagli case by quoting extracts. It deserves to be read in extenso. 
the late Professor Westlake, "that the domicile in such a case should be denoted by a compound name, of which one element should indicate the territory and the other the community." 4 William Edward Hall defended the same nomenclature. ${ }^{40}$ Compound names are practically inseparable, however, from a distorted conception of domicil. $^{\text {.0 }}$ While they may be useful in describing the lex domicilii under consular jurisdiction, it is submitted, with all deference to the distinguished authority of Hall and Westlake, that as applied to domicil they are at least misleading and superfluous. The multiplication of technical terms is "an evil only to be justified by necessity," and domicil is domicil, from however many sources the lex domicilii may be derived.

The idea of a hyphenated domicil compounded of relation to locality and membership in a community was repudiated in Tootal's Trusts. ${ }^{51} \mathrm{Mr}$. Justice Chitty's dictum suggested another query, however, as to whether domicil can be acquired under what may be described as a hyphenated lex domicilii. Does the partition of jurisdiction between the territorial and the exterritorial authorities in case of consular jurisdiction constitute an insuperable obstacle to the acquisition of domicil? It was intimated in Tootal's Trusts and Abdul-M essih v. Chukri Farra that such an obstacle inheres in the nature of consular jurisdiction. Mr. Charles H. Huberich has suggested that the difficulty arose out of an erroneous conception of exterritoriality. He believes that it is possible to regard the state which concedes exterritorial privileges as supreme over all persons and things within its territorial limits and to explain exterritorial jurisdiction as a mere delegation of authority. He concludes,

"The legislative power of China extends to all persons and things within the territorial limits of the Empire; the British

\footnotetext{
43 Law Magazine and Review (4th series) 363, 372. See also his Private International Law (4 ed.), 31 r-322.

to Foreign Jurisdiction of the British Crown, 184-186.

$\infty$ This is well illustrated by Hall's defence of the notion of Anglo-Oriental domicil. He says: "Theoretically the conception of such a domicil is unobjectionable if once the mind is cleared of the notion, at present dominant, that domicil is the creature of place and intention alone. In Europe it is so, because residence in a place implies subjection to the common territorial law, and to no other; in the East it is not necessarily so, because residence there implies subjection to the law of one or other of several different communities the personal laws of which receive equal recognition from the territorial sovereign power. Association with place is necessary to domicil; but it is not always the sole determinant factor. In any case, even if the conception of domicil here suggested be anomalous, the convenience of giving effect to it is large enough to excuse a certain sacrifice of logical principle." $O_{p .}$ cit., 186.

sx Strictly speaking, that was all that Tootal's Trusts decided, and on that point it is submitted that the decision was correct.
} 
Parliament in legislating for British nationals in China acts merely under a delegation of authority. Such laws are operative within the territory of China only, because China recognizes them as part of the law of the land. The Chinese law subjects certain persons owing allegiance to a foreign government to rules of law which may differ from those that are applied to persons of Chinese nationality, just as the common law subjects certain transactions having their origin in foreign countries to rules of law which may differ from those that are applied to transactions taking place in the forum. Nor is the principle affected by the circumstarice that this law is administered by officials appointed by a foreign government."s2

In other words, the partition of jurisdiction which seems to have troubled the English courts does not really exist. This explanation appears to have been approved in Mather v. Cunningham, where it was said,

"The ownership of the soil, therefore, controls the establishment of all local laws. Without consent of the owner, no extraterritorial law can be enacted within an independent jurisdiction,-or extended to it. China is independent. It never released its ownership to the soil of Shanghai. Its sovereignty over its territory was jretained $* * *$ whatever laws may have been extended by Congress to the Province of Shanghai are operative, not upon American soil, but upon the territory of the Chinese Empire. How do these laws reach there? By treaty, permission of the Emperor.*** Although the Emperor had suspended some of the Chinese laws and permitted the extension of American law to the territory, yet the source of the law was the Emperor who had never released his sovereignty over the soil."\$s

The above explanation was in no way essential to the decision in Mather v. Cunningham, however, for the decision was based upon the principle that domicil is independent of any distinction with respect to the source of the lex domicilii.

Consular jurisdiction was not explained as a mere delegation of authority in the American case of Allen's Will.s4 The English

\footnotetext{
62 24 Law Quarteriy Review 440, 448. Compare Westlake, 9 Law Magazine and Review (4th series) 368.

105 Me. $326,337,338$. The opinion is not as clear on this point, however, as the extracts quoted above might seetn to indicate.

* Judge Wilfey said, "while the Emperor of China exercises nominal sovereignty over
} 
cases have insisted throughout that the concession of exterritorial privileges involves a real partition of jurisdiction. ${ }^{\text {ss }}$ The most recent expression on this point is found in the Casdagli case, where it was said,

"It is not by reason of any local law that a British protected person in Egypt is to be immune from local law. and that his own law is to be applied to him by His Britannic Majesty's Courts, sitting in Egypt, on Egyptian soil, but deriving their authority from His Majesty; such jurisdiction is indeed in derogation of the power of the Sovereign of the country conferring such rights $* * *$ and the law administered in Egypt by His Britannic Majesty's Courts is English law and not Eigyptian local law. ${ }^{56 * * *}$ With all respect to the American judges who, in Mather v. Cunningham*** expressed a contrary view, I am of opinion that the Consular Court in Egypt is one of the King's Courts, that its jurisdiction is derived from the King, and not from the Ruler of Egypt, and that the law administered therein is strictly the law of England, and is not to be regarded as a branch of the law of Egypt."

It would seem that the English courts are abundantly.justilied in insisting that the law stick to realities. The theory of delegated authority is false to the facts. Moreover, it is superfluous. The difficulty has not arisen out of an erroneous conception of consular jurisdiction. It has arisen out of a distorted idea of domicil which, it has been suggested, seems to have had its inception in a confusion of domicil with lex domicilii. L,et the importance of preserving a clear distinction between domicil and the lex domicilii be fully understood,

all Chinese territory including that occupied by the nationals of the United States and Great Britain, yet the jurisdiction of these two countries over their own citizens who reside in China is, for all practical purposes, as full and complete as if China were in fact territory belonging to these nations." I American Journal of International Law ro29, 1034.

w In Tootal's Trusts, Justice Chitty said, "The sovereignty over the soil at Shanghai remains vested in the Emperor of China with this exception, that he has by treaty bound himself to permit British subjects to reside at the place for purposes of commerce only, without interference on his part, and to permit the British Crown to exercise jurisdiction there over its own subjects, but over no other persons." 23 Ch. D. 532, 539. See also Papayanni v. The Russian Steam Navigation and Trading Compary, 2 Moore P. C., N. S. 161 (1863); Imperial Japanese Government v. The Peninsular and Oriental Steam Navigation Company, 64 L. J. P. C. I07, I12, I13 (1895); Secretary of State for Foreign Affairs v. Charlesworth, Pilling and Co., 70 L. J. P. C. 25, 28, 29 (Ig0r). Compare the language used in the Foreign Jurisdiction Act, 1890,53 \& 54 Vict. c. 37.

s4 Swinfen Eady, L. J., 87 L. J. P. 79, 81.

67 Warrington, L. J., 87 L. J. P. 79, 83, 84. See Scruttòn, L. J., ibid., 9I, 92. 
and there should be no difficulty in admitting the possibility of domicil under consular protection. The lex domicilii will have a dual source, but that is a phenomenon by no means entirely unknown to the law. Something of the sort exists in case of federations, confederations, and loosely constituted empires. In international relationships phenomena that are similar in some respects at least result from military occupation, prolonged intervention, protection, financial supervision of debtor states, the administration of territory, the leasing of territory, and divers limitations of the nature of servitudes. There is no reason why a partition of jurisdiction which involves a lex domicilii derived from a dual source should be regarded as an insuperable obstacle to the acquisition of domicil.

The English conception of consular jurisdiction is sound enough, but the English rule which denies the possibility of acquiring a domicil of choice under consular jurisdiction is at once illogical and impractical. Its consequences have never been sufficiently considered. A British subject cannot acquire a domicil of choice abroad under consular protection. He cannot have a. matrimonial donicil under consular protection. A fortiori his children born under exterritorial jurisdiction can have no domicil of origin at their place of birth. And so on for as many generations as one chooses to postulate. This is not mere idle speculation for there are many British families which have been settled for several generations under British consular jurisdiction. Domicil in such cases must be domicil of some ancestor. The manifold inconveniences necessarily incident to the application of the doctrine of ancestral domicil are too obvious for comment. ${ }^{58}$ Although residence and the animus manen$d i$ in an exterritorial community cannot destroy a domicil of origin, they must, from the very circumstances of the case, destroy a previous domicil of choice, since the conditions under which that domicil arose have been terminated. Having destroyed a previous domicil of choice, they operate to revive a pre-existing domicil of origin. although there is, ex hypothesi, no animus revertendi to that domicil. In other words, we have what Sir Francis Piggott has aptly described as "a mechanical contrivance for supplying a want of definite intention" applied to a case where there are definite intention and every ingredient and every idea involved in the assumption of a new domicil. ${ }^{58}$

It has been suggested that there may be other jurisdictional anomalies in which the lex domicilii is derived from a dual source. If the

ss See Hall, Foreign Jurisdiction of the British Crown, 185; Westlake, 9 Law Magazine and Review (4th series) 374 .

50 Exterritoriality (new ed.), 230. 
point were raised, would consistence require that the doctrine of Casdagli v. Casdagli be applied to such situations? There are other types of cases in which the matter of domicil presents a problem of considerable difficulty and importance. Will the conception of domicil approved in the Court of Appeal be extended to such cases ?60 Is it too much to say that eventually the English courts must consider this problem on itc merits and with more or less disregard for the ancient doctrine of immiscibility, the analogies with commercial and Anglo-Indian domicil, and the accumulated dicta of distinguished judges. A generation has elapsed since Tootal's Trusts was decided and the problem still requires further examination in the House of Lords or the Privy Council. Meanwhile American courts will find in the ratio decidendi of Mather v. Cunningham a satisfactory principle and precedent.

Ann Arbor, Mich.

EDWIN D. Dickinson.

(Compare, for example, the problems involved in In re Johnson, 72 L. J. Ch. 682 (1903); In re Bowes, 22 Times L. R. 71I (I906).

Note:-Since the above article was written it has come to the author's notice that the decision of the Court of Appeal in the case of Casdagli v. Casdagli was reversed in the House of Lords October 28, I918. International Law Notes, Dec., 1918, p. 169; The Solicitor's Journal and Weekly Reporter, Nor. 2, 19I8, p. 39. The opinions given in the House of Lords are not yet available. Such summaries as have been published indicate that a satisfactory solution has at last been found for the problem of domicil under consular jurisdiction in the English law. The decision of the House of Lords will be discussed in a later paper when the opinions become available. 